\title{
Impact of Bio-Fertilizer EM and Plants Dried Leaf Powders of Water Hyacinth or Turmeric on Tomato Plants Infected by Meloidogyne incognita at Greenhouse Conditions. \\ El-Sherif, A. G. ${ }^{1}$; H. A. El-kady ${ }^{2}$; S. B. Gad ${ }^{1}$ and M. M. Shalaby ${ }^{3}$ \\ ${ }^{1}$ Nematology Research Unit, Agric. Zoology Dept. Fac. of Agric., Mansoura Univ., Egypt. \\ ${ }^{2}$ Economic Entomology Dept. Fac. of Agric., Damietta Univ., Egypt. \\ ${ }^{3}$ Agric. Zoology Dept. Fac. of Agric., Damietta Univ., Egypt.
}

\section{ABSTARCT}

A pot assessment was conducted to verify the impact of bio-fertilizer EM and dried powder of water hyacinth plant (Eichhornia Crassipes) or turmeric plant (Curcuma longa) either or integrated applications on plant reaction of tomato seedlings cv. $888 \mathrm{~F} 1$ infected by $M$. incognita at greenhouse conditions. It is remarkable to detect that the experienced binary applications accomplished better results than single ones did. Evidently, data showed that all tested components enhanced tested plant criteria and also diminished nematode parameters. The bio-fertilizer EM application plus dry-leaf powder of water hyacinth plant mixed with oxamyl at triple doses each showed the maximum value of whole plant length (73.0\%), whole plant fresh weights $(231.8 \%)$, shoot dried weight $(246.8 \%)$, leaves number $(126.52 \%)$ and branches number $(41.51 \%)$, respectively. In the meantime, the tetra application of (bio-fertilizer EM + turmeric + water hyacinth +oxamyl) accomplished the maximum decrease percentage in total nematode final density, galls and egg-masses number with values of $97.4,86.5$ and $91.5 \%$, correspondingly. It was obvious that nitrogen, phosphorus, potassium concentration, chlorophyll and phenol contents were apparently reduced by nematode infectivity by deferent degrees. All tested applications showed significant increase percentages of in nitrogen, phosphorus, potassium concentration, chlorophyll and phenol contents greater than those of nematode alone.

Keywords: Bio-fertilizer, EM, dried leaf powders, water Hyacinth, turmeric, control, M. incognita.

\section{INTRODUCTION}

The significance of phyto-nematodes as a limitation on successful economic agricultural yield production was known since ancient times. The realization of pathogens chemical control improved the attention in additional alternative methods of agriculture pest control. Economic crops pest protection for greater yield production has to be friendly with sustainability, with no causing any injure to the environment. The southern root-knot nematodes, Meloidogyne spp., are known all over the world as one of the mainly injurious plant pathogens worldwide (Trudgill \& Block 2001). Injure caused by $M$. incognita is especially greater on vegetable plantations in tropical and subtropical regions (Sikora \& Fernandez, 2005). The require for biologically produced materials is rising all over the world by reason of mounting concerns concerning of environmental and food. In this regard, plant disease control can be achieved by several alternative methods i.e. crop rotation, intercropping, organic manuring, resistance cultivars and bio control agents. The bio-fertilizer EM is stands for effective microorganisms that is not specific variety of microorganisms which is a liquid solution containing lactic photosynthetic, acid bacteria plus nitrogen fixing bacteria, yeast, ray fungi and molds (Higa and Wididana, 1991). Appliance of EM is notorious to augment the microbial diversity of soil and plants, improve soil quality, and increase yield and quality of crops (Kishore, 2000). Water hyacinth leaf extract exhibit phytotoxicity to Mimosa pigra and inhibited seeds germination. The inhibitory property might be to improved production of hydrogen peroxide, soluble peroxidase inhibition activity, and encouragement of cell wall activity of bound peroxidase (Chai et al., 2013).Water hyacinth is also given effective in controlling micro-organisms such as fungi and bacterial diseases in plants plus humans because of its phytochemical compounds (Lata and Venapani, 2010).The turmeric plants (Curcuma longa) showed efficient in controlling against agricultural pests because of the attendance of a diversity of bio-active constituents
(Christos, 2012). The current study was set to determined the efficacy of bio-fertilizer EM and dried powder of water hyacinth or turmeric plants either as single or integrated applications in comparison with a nematicide (oxamyl) on tomato seedlings growth reaction cv. $888 \mathrm{~F} 1$ infected by $M$. incognita in greenhouse conditions $\left(25 \pm 3^{\circ} \mathrm{C}\right)$.

\section{MATERIALS AND METHODS}

Nematode preparing inoculums:

Infected root systems of coleus plants, Coleus blumei, by very heavy root-knot nematode eggmasses that previously identified as $M$. incognita were washed via water, then sited in the container with enough solution of $1.0 \% \mathrm{NaOCl}$ and manually shake for $60 \mathrm{sec}$. and speedily passed out of sieves (500 mesh) as well as carefully the collected eggs washed with water (Hussey \& Barker, 1973). Finally, the numbers of egg for each unit amount of water was counted and after that plants were inoculated with nematode eggs as to the trial design.

Pesticide (Oxamyl (Vydate 24\% L) : Methyle-N-Ndimethyl-(N-(methyl) carbomycocyl) -1-Thioxamidate.

Preparation of dried leaf powders of hyacinth and turmeric plants.

Indentified leaves of water hyacinth and turmeric weresun- dried for three days then grinded in a grinder and sieved through a 25 um sieve to obtain a fine powder.

Impact of bio-fertilizer EM and dried powder of water hyacinth or turmeric plants singly or integrated on the nematode, Meloidogyne incognita as compared to oxamyl in greenhouse conditions $\left(25 \pm 3^{\circ} \mathrm{C}\right)$.

The effect of water hyacinth, turmeric as dried leave powders; and bio-fertilizer EM as single or integrated plus oxamyl on the root-knot nematode, $M$. incognita as compared with oxamyl was determined at greenhouse $\left(25 \pm 3^{\circ} \mathrm{C}\right)$. Fifty-two plastic pots $(15 \mathrm{~cm})$ were filled with $1600 \mathrm{~g}$. steam-sterilized clay sand soil $(1: 1, \mathrm{v}$ : v) and received one (30 day-old seedling) tomato each. One week later, $M$. incognita eggs inocula was added to 
forty eight plastic pots. One week later, the dried powder of water hyacinth, turmeric, as well as biofertilizer EM was added according to experiment design and mixed with soil, whilst four inoculated pots treated by oxamyl at $0.3 \mathrm{~g} /$ pot each. Four plant pots inoculated by nematode only and with no any treatment were serve as nematode check. Every treatment was with four replications. This experiment included 14 treatments as follows:

1- $\mathrm{N}+$ Bio-fertilizer EM adding ( $5 \mathrm{ml} /$ pot $)$,

2- $\mathrm{N}+$ Turmeric dried leaf powder( $5 \mathrm{~g} /$ plant $)$,

3- $\mathrm{N}+$ water hyacinth dried leaf powder $(5 \mathrm{~g} / \mathrm{pot})$,

4- $\mathrm{N}+1 / 2$ (bio-fertilizer EM+ Oxamyl),

5- $\mathrm{N}+1 / 2$ (turmeric + Oxamyl),

6- $\mathrm{N}+1 / 2$ (water hyacinth + Oxamyl),

7- $\mathrm{N}+1 / 3$ (bio-fertilizer EM+ turmeric + Oxamyl),

8- $\mathrm{N}+1 / 3$ (bio-fertilizer EM + water hyacinth + oxamyl),

9- $\mathrm{N}+1 / 3$ (water hyacinth + turmeric + oxamyl)

$10-\mathrm{N}+1 / 4$ (bio-fertilizer EM + turmeric + water hyacinth + Oxamyl),

$11-\mathrm{N}+$ oxamyl $(0.3 \mathrm{ml} / \mathrm{pot})$,

12-Nematode Check

13- Plant without nematode and treatment.

Plant pots were set in design of randomized

complete block at greenhouse and treated irrigated as required. The tested Plants were up-rooted forty five days after beginning of nematode inoculation. Plant criteria such as plant length, fresh root and shoot weights, dried shoot weights, leaves and branches number were determined and recorded. Infected plant roots of were washed by water, fixed in $4 \%$ formalin for one day and examined for the numbers of gall and eggmass in root system and recorded. Root gall (RGI) and egg-mass (EI) indices were valued as recorded by Taylor and Sasser (1978).

\section{Chemical analysis:}

Total nitrogen \% was determined by the distillation in a macrokjeldahl apparatus (Helrich, K. 1990). Phosphorus and potassium were determined photo-metrically using flame photometer, as described by Ranganna(1979).

Chlorophyll ( $\mathrm{a}$ and $\mathrm{b}$ ) were recorded and determined as to Machinney (1941). Freshly leaves $(0.05 \mathrm{~g})$ were left overnight at $10 \mathrm{ml}$ methanol at $4^{\circ} \mathrm{C}$ in incidence traces with sodium bicarbonate at a tube enclosed with aluminum foil. Spectrophotometrically at wave lengths 650 and $665 \mathrm{~nm}$ were used to calculate the color, by the equations as described by Machinney (1941). Determination of phenols were after harvesting in freshly roots and stems by the Folin Ciocalteau reagent (Kaur and Kapoor 2002).

Statistically, data were analyzed to variance according to then compare means (Gomez \& Gomez, 1984; Duncan, 1955).

Table 1. Plant products used as soil organic amendments.

\begin{tabular}{|c|c|c|c|c|c|}
\hline No. & $\begin{array}{l}\text { English } \\
\text { name }\end{array}$ & $\begin{array}{l}\text { Scientific } \\
\text { name }\end{array}$ & Family & $\begin{array}{c}\text { Phytochemical } \\
\text { analysis }\end{array}$ & $\begin{array}{c}\text { Arabic } \\
\text { name }\end{array}$ \\
\hline 1 & $\begin{array}{c}\text { water } \\
\text { hyacinth }\end{array}$ & $\begin{array}{c}\text { Eichhornia } \\
\text { crassipes }\end{array}$ & Pontedariaceae & $\begin{array}{c}\text { Tannins, saponins, alkaloid, flavonoid, phenol and } \\
\text { quinoneswas carried out in the laboratory using the } \\
\text { methods described by Sofowora (1993) and Trease } \\
\text { and Evans (1989). }\end{array}$ & ورد النيل \\
\hline 2 & Turmeric & $\begin{array}{c}\text { Curcuma } \\
\text { longa }\end{array}$ & Zingiberaceae & $\begin{array}{l}\text { Flavanoids, Cardiac, glycosides and Phenols in } \\
\text { both the varieties of turmeric leaves by R. Arutselvi } \\
\text { et al (2012). }\end{array}$ & الكركم \\
\hline
\end{tabular}

\section{RESULTS AND DISCUSSION}

Data as depicted at table (2) verified the efficacy of bio-fertilizer EM and dried plant powders of water hyacinth and turmeric only or integrated applications with oxamyl comparing to nematicide (oxamyl) versus M. incoginta infecting tomato seedlings cv. $888 \mathrm{~F} 1$ in greenhouse $\left(25 \pm 3^{\circ} \mathrm{C}\right)$. Visibly, results showed that whole tested materials perceptibly enhanced plant tested criteria and decrease nematode reproduction too. Amongst single applications, plant treated by biofertilizer EM surpassed other tested single treatments in the increment vulvas of total plant length $(3.4 \%)$, total plant fresh weight (16.7\%), shoot dried weight (15.6\%), number of leaves $(55.49 \%)$ and branches $(9.43 \%)$ followed by water hyacinth dry-leaf powder in this respect comparing to nematode alone (Table1). Moreover, among the dual treatments tested in this study, turmeric dried leaf powder plus oxamyl at their half doses overwhelmed other double treatments in the percentage increase values of such plant growth characters of tomato plant i.e. total plant length $(55.2 \%)$, total plant fresh weight $(133.3 \%)$, shoot dried weight (123.1\%), number of leaves (124.09\%) and branches
(37.74\%) followed by that of $1 / 2$ (water hyacinth dried leaf powder $+\mathrm{Ox})$ and then $1 / 2($ bio-fertilizer $\mathrm{EM}+\mathrm{Ox})$ in comparison to nematode only application, respectively. Similarly, the alike trend was clear as the application of bio-fertilizer EM plus water hyacinth dry-leaf powder mixed with oxamyl at triple doses each as achieved the maximum increase percentage values of $73.0 \%$, $231.8 .0 \%, 246.8 \%, 126.52 \%$ and $41.51 \%$ for the same parameters followed by that of $1 / 3$ (turmeric dried leaf powder + water hyacinth dried leaf powder + oxamyl) and then $1 / 3$ (bio-fertilizer EM + turmeric dried powder + oxamyl) for the plant parameters, respectively. Furthermore, parallel tendency was too strongly observed in the tetra application, 1/4 (bio-fertilizer EM + turmeric + water hyacinth +oxamyl) which achieved considerable percentages of increase with values 40.2, $89.4,82.2,87.50$ and 32.08 for plant total length, fresh weights, shoot dried weight as well as leaves and branches number, respectively. The systemic nematicide (oxamyl) recorded moderately significant increase percentage values of plant growth characters, since its values were amounted to $27.8,40.9,44.8,67.68$ and 
$22.64 \%$ for plant length, fresh weight, shoot dried weight as well as leave and branch numbers of, respectively, comparing to nematode alone (Table 2). Regarding healthy plants that free of nematode and any treatment, it has increase percentage values of 29.2 , $87.9,79.5,81.40$ and $28.30 \%$ for the same plant growth criteria, respectively (Table 2).

Table 2. Impact of impact of bio-fertilizer EM and dried leaf powders of water hyacinth or turmeric either alone or mixed as double or triple or tetra applications with oxamyl in assessment with oxamyl on plant growth reaction of tomato plant cv. $888 \mathrm{~F} 1$ infecting with Meloidogyne incognita at greenhouse conditions $\left(25 \pm 3^{\circ} \mathrm{C}\right)$.

\begin{tabular}{|c|c|c|c|c|c|c|c|c|c|c|c|c|c|c|}
\hline \multirow{3}{*}{ Treat. } & \multicolumn{14}{|c|}{ Plant growth response } \\
\hline & \multicolumn{4}{|c|}{$\begin{array}{c}\text { Plant Length } \\
(\mathrm{cm})\end{array}$} & \multicolumn{4}{|c|}{$\begin{array}{c}\text { Plant Fresh weight } \\
\text { (g) }\end{array}$} & \multicolumn{2}{|c|}{$\begin{array}{l}\text { Shoot } \\
\text { dried }\end{array}$} & \multirow{2}{*}{$\begin{array}{c}\text { No. } \\
\text { of } \\
\text { leaves }\end{array}$} & \multirow{2}{*}{$\begin{array}{c}\text { Inc. } \\
\%\end{array}$} & \multirow{2}{*}{$\begin{array}{c}\text { No. } \\
\text { of } \\
\text { branches }\end{array}$} & \multirow{2}{*}{$\begin{array}{c}\text { Inc. } \\
\%\end{array}$} \\
\hline & shoot & Root & Total & $\begin{array}{c}\text { Inc. } \\
\%\end{array}$ & Shoot & Root & Total & $\begin{array}{c}\text { Inc. } \\
\%\end{array}$ & $\begin{array}{l}\text { wg } \\
(g)\end{array}$ & $\begin{array}{c}\text { Inc. } \\
\%\end{array}$ & & & & \\
\hline Bio- -1 & & & $36.8 \mathrm{e}$ & 3.4 & & .78 & & 16.7 & $1.13 \mathrm{i}$ & 15.6 & & & & 9.43 \\
\hline -leaf powder $5 \mathrm{~g}$ & & & & 0.6 & & $2.4 \mathrm{c}$ & & 3.0 & 1.021 & 4.3 & & & & 3.77 \\
\hline $\begin{array}{l}\text { Water hyacinth dry-leaf } \\
\text { powder } 5 \mathrm{~g}\end{array}$ & 26.3 de & $10.0 \mathrm{e}$ & $36.3 \mathrm{e}$ & 2.0 & $4.2 \mathrm{~d}$ & $2.7 \mathrm{c}$ & $7.4 \mathrm{de}$ & 12.1 & $1.06 \mathrm{k}$ & 8.8 & $43.8 \mathrm{cde}$ & 33.54 & $5.5 \mathrm{bc}$ & 3.77 \\
\hline $1 / 2(\mathrm{EM}+\mathrm{Ox})$ & $19.8 \mathrm{f}$ & $16.8 \mathrm{~cd}$ & $36.5 \mathrm{e}$ & 2.5 & $5.5 \mathrm{~cd}$ & $2.0 \mathrm{c}$ & $7.5 \mathrm{de}$ & 13.6 & $1.12 \mathrm{j}$ & 14.4 & 49.5 bcde & 50.91 & $5.8 \mathrm{abc}$ & 9.43 \\
\hline $1 / 2($ turmeric $+\mathrm{Ox})$ & $3.3 \mathrm{ab}$ & $22.0 \mathrm{~b}$ & $55.2 \mathrm{~b}$ & 55.1 & $.5 \mathrm{~b}$ & $5.9 \mathrm{ab}$ & $15.4 \mathrm{~b}$ & 133.3 & $2.18 \mathrm{~b}$ & 123.1 & $73.5 \mathrm{a}$ & 124.09 & $7.3 \mathrm{ab}$ & 37.74 \\
\hline $1 / 2$ (water hyacinth $+O x)$ & 28.0 cde & $16.8 \mathrm{~cd}$ & $44.8 \mathrm{~cd}$ & 25.8 & $5.5 \mathrm{~cd}$ & $3.7 \mathrm{bc}$ & $9.3 \mathrm{cde}$ & 40.9 & $1.27 \mathrm{~g}$ & 30.4 & $53.0 \mathrm{bcd}$ & 61.59 & $6.3 \mathrm{abc}$ & 18.87 \\
\hline $1 / 3(\mathrm{EM}+$ turmeric $+\mathrm{Ox})$ & $28.5 \mathrm{~cd}$ & $13.3 \mathrm{de}$ & $41.8 \mathrm{de}$ & 17.4 & $4.7 \mathrm{~cd}$ & $3.4 \mathrm{bc}$ & $8.1 \mathrm{de}$ & 22.7 & $1.8 \mathrm{~h}$ & 30.2 & 51.0 bcde & 55.49 & $6 \mathrm{abc}$ & 13.21 \\
\hline $1 / 3(\mathrm{EM}+$ water hyacinth $+\mathrm{Ox})$ & $36.6 \mathrm{a}$ & $25.0 \mathrm{a}$ & $61.6 \mathrm{a}$ & 73.0 & $15.5 \mathrm{a}$ & $6.4 \mathrm{a}$ & $21.9 \mathrm{a}$ & 231.8 & $3.39 \mathrm{a}$ & 246.8 & & 126.52 & $7.5 \mathrm{a}$ & 41.51 \\
\hline $1 / 3$ (turmeric + water hyacinth $+O x)$ & $31.7 \mathrm{bc}$ & $19.3 \mathrm{bc}$ & $50.9 \mathrm{bc}$ & 43.0 & $8.7 \mathrm{~b}$ & $4.7 \mathrm{abc}$ & $13.4 \mathrm{bc}$ & 103.0 & $2.12 \mathrm{c}$ & 117.0 & $68.3 \mathrm{ab}$ & 108.23 & $7.3 \mathrm{ab}$ & 37.74 \\
\hline $\begin{array}{l}1 / 4(\mathrm{EM}+\text { turmeric + water hyacinth } \\
+\mathrm{Ox})\end{array}$ & $33.4 \mathrm{ab}$ & $16.5 \mathrm{~cd}$ & $49.9 b c$ & 40.2 & $7.7 \mathrm{bc}$ & $4.8 \mathrm{abc}$ & $12.5 \mathrm{bcd}$ & 89.4 & $1.78 \mathrm{~d}$ & 82.2 & $61.5 \mathrm{abc}$ & 87.50 & $7 \mathrm{abc}$ & 32.08 \\
\hline Oxamyl & & & & 27.8 & & $3.7 \mathrm{bc}$ & & 40.9 & $1.42 \mathrm{f}$ & 44.8 & & 67.68 & & 22.64 \\
\hline $\mathrm{N}$ alone & $9.3 \mathrm{f}$ & $16.4 \mathrm{~cd}$ & $35.6 \mathrm{e}$ & --- & $4.0 \mathrm{~d}$ & $2.6 \mathrm{c}$ & $6.6 \mathrm{e}$ & --- & $0.98 \mathrm{~m}$ & --- & $32.8 \mathrm{e}$ & 0.00 & & 0.00 \\
\hline & $26.3 \mathrm{de}$ & $19.8 \mathrm{bc}$ & $46.0 \mathrm{~cd}$ & 29.2 & & $3.4 \mathrm{bc}$ & $12.4 \mathrm{bcd}$ & 87.9 & $1.76 \mathrm{e}$ & 79.5 & $59.5 \mathrm{abcd}$ & 81.40 & $6.8 \mathrm{abc}$ & 28.30 \\
\hline $\mathrm{LSD}_{\mathrm{P}=5 \%}$ & 3.0 & 3.0 & 4.7 & --- & 2.1 & 1.7 & 3.5 & --- & 1.4 & --- & 12.9 & --- & 1.1 & \\
\hline
\end{tabular}

$\mathbf{N}=1000$ eggs of Meloidogyne incognita

* Each figure is the mean of four replicates.

$* *$ Increase $\%=($ Treatment $-\mathbf{N}$ alone $) / \mathbf{N}$ alone $\times 100$.

Means in each column followed by the same letter(s) did not differ at $\mathbf{P}<\mathbf{0 . 0 5}$ according to Duncan's multiple-range test.

Data presented in Table (3) revealed the efficacy of bio-fertilizer EM or water hyacinth or turmeric dried leaf powders against $M$. incoginta infecting tomato plant cv. 888 F1 under greenhouse conditions. Generally, results indicated that whole treatments apparently reduce $M$. incognita tested criteria i.e. juveniles in soil, developmental stages, root galling, females and egg masses on root system. It is attractive to detect that the tested dual or triple or tetra applications stated better results than solitary ones did. Meanwhile, amongst the single applications, turmeric dried leaf powder achieved the maximum reduction percentage of nematode parameters with the maximum values of $71.7,71.3$ and $84.6 \%$ for final nematode population, galls and eggmasses numbers, respectively (Table 3 ).

Moreover, plant receiving bio-fertilizer EM as a single treatment ranked second to turmeric dry-leaf powder in reducing nematode parameters values that amounted to $60.9,71.1$ and $81.9 \%$, for the same parameters. On the other hand, water hyacinth dried leaf powder showed the least values in this respect which were appointed to $57.7,64.1$ and $81.0 \%$ for same parameters, respectively. As far the dual applications, bio-fertilizer EM plus oxamyl at its half doses achieved the highest reduction values of final nematode population (87.8), number of galls (83.0) and egg masses (89.4), followed by that of $1 / 2$ (turmeric dried powder +oxamyl). It is interesting to observe that when the dual applications applied with oxamyl as triple treatment, an obvious synergistic action of such triple application was clear in resulting more reduction percentage of nematode criteria. For instance, plant receiving $1 / 3$ (turmeric dried leaf powder + bio-fertilizer EM + oxamyl) surpassed over other tested triple treatments in reducing final nematode population $(82.9 \%)$, number of galls $(89.8 \%)$ and egg masses $(96.2 \%)$, followed by that of $1 / 3$ (turmeric dried leaf powder + water hyacinth dried leaf powder + oxamyl), respectively.

Moreover, when oxamyl added to such triple as tetra application of $[1 / 4$ (bio-fertilizer EM + water hyacinth dried leaf powder + turmeric dried leaf powder + oxamyl)], a high synergistic action was obviously recorded in diminishing nematode parameters with values of $97.4,86.5$ and $91.5 \%$, respectively. It is valuable to reminder that oxamyl recorded the highest reduction percentages of final nematode population (86.4\%), galls (90.7\%) and egg masses (96.3\%) number, respectively as ranked first in this respect. Similarly, significance results were noticed between egg masses indices of whole tested treatment and nematode only, since they ranged between 2 to 4 for tested applications vs 5 for nematode alone (Table 3 ).

Also, nematode reproduction factors (RF) were adversely affected which the application of $1 / 4$ (bio-fertilizer EM + water hyacinthdry-leaf powder + turmeric dried powder + oxamyl) had the lowest rate of reproduction (0.34) whilst that of water hyacinth dry-leaf powder alone showed clearly the highest (1.07), respectively, whereas oxamyl had the least value (0.30) in this respect. Promising 
results were reported among the tested applications of adding bio-fertilizer EM with water hyacinth dried leaf powder and oxamyl plus turmeric dried powder at $1 / 4$ each doses which showed few number of females (8.5), galls (10.3), egg masses (3.8) and juveniles (329/1 kg soil), respectively(Table 3$)$.

Table 3. Nematode parameters of Meloidogyne incognita infecting tomato plants $\mathrm{cv} .888 \mathrm{F1}$ as affected by biofertilizer EM anddried powders of water hyacinth or turmericeither alone or mixed as double or triple or tetra application in comparison with oxamyl under greenhouse conditions $\left(25 \pm 3{ }^{\circ} \mathrm{C}\right)$.

\begin{tabular}{|c|c|c|c|c|c|c|c|c|c|c|c|c|}
\hline \multirow{3}{*}{ Treatment } & \multicolumn{12}{|c|}{ Nematode parameters } \\
\hline & \multicolumn{3}{|c|}{ Nematode population in } & \multirow[b]{2}{*}{ Total } & \multirow[b]{2}{*}{ RF } & \multirow{2}{*}{$\underset{\%}{\text { Red. }}$} & \multirow{2}{*}{$\begin{array}{c}\text { No. of } \\
\text { galls }\end{array}$} & \multirow{2}{*}{$\begin{array}{c}\text { Red. } \\
\%\end{array}$} & \multirow[b]{2}{*}{ RGI } & \multirow{2}{*}{$\begin{array}{c}\text { No. of egg } \\
\text { masses }\end{array}$} & \multirow{2}{*}{$\underset{\%}{\text { Red. }}$} & \multirow[b]{2}{*}{ EI } \\
\hline & $\begin{array}{c}\text { Soil/pot } \\
\text { J2 }\end{array}$ & $\begin{array}{l}\text { D.V. } \\
\text { stage }\end{array}$ & Females & & & & & & & & & \\
\hline Bio-fertilizer EM 5ml & $795.8 \mathrm{~b}$ & $49.5 \mathrm{~b}$ & 39.5 bcd & $884.8 \mathrm{~b}$ & 0.88 & 64.9 & $32.0 \mathrm{bc}$ & 71.1 & 4 & $18.8 \mathrm{~b}$ & 81.9 & 3 \\
\hline Turmeric dry-leaf powder $5 \mathrm{~g}$ & $625.5 \mathrm{c}$ & $42.9 \mathrm{bc}$ & $44.5 \mathrm{bc}$ & $712.7 \mathrm{c}$ & 0.71 & 71.7 & $31.8 \mathrm{bc}$ & 71.3 & 4 & $16.0 \mathrm{bc}$ & 84.6 & 3 \\
\hline Water hyacinth dry-leaf powder $5 \mathrm{~g}$ & $872.5 \mathrm{~b}$ & $35.0 \mathrm{c}$ & $57.8 \mathrm{~b}$ & $965.3 \mathrm{~b}$ & 0.97 & 61.7 & $39.8 \mathrm{~b}$ & 64.1 & 4 & $19.8 \mathrm{~b}$ & 81.0 & 3 \\
\hline $\left.1 / 2^{(E M}+O x\right)$ & $489.5 \mathrm{~d}$ & $10.0 \mathrm{e}$ & 34.5 bcde & $534.0 \mathrm{def}$ & 0.53 & 78.8 & $18.8 \mathrm{cde}$ & 83.0 & 3 & $11.0 \mathrm{bc}$ & 89.4 & 3 \\
\hline $1 / 2($ turmeric $+\mathrm{Ox})$ & $558.3 \mathrm{~d}$ & $12.8 \mathrm{e}$ & $22.5 \mathrm{cdef}$ & $593.5 \mathrm{de}$ & 0.59 & 76.4 & $28.5 \mathrm{bcd}$ & 74.3 & 3 & $12.5 \mathrm{bc}$ & 88.0 & 3 \\
\hline $1 / 2$ (water hyacinth $+\mathrm{Ox})$ & $560.0 \mathrm{~d}$ & $24.7 \mathrm{~d}$ & $40.5 \mathrm{bc}$ & $625.3 \mathrm{~d}$ & 0.63 & 75.2 & $31.5 \mathrm{bc}$ & 71.6 & 4 & $14.0 \mathrm{bc}$ & 86.6 & 3 \\
\hline 1/3 $(\mathrm{EM}+$ turmeric $+\mathrm{Ox})$ & $409.8 \mathrm{def}$ & $8.7 \mathrm{e}$ & $12.5 \mathrm{ef}$ & $431.0 \mathrm{fgh}$ & 0.43 & 82.9 & $11.3 \mathrm{e}$ & 89.8 & 3 & $4.0 \mathrm{c}$ & 96.2 & 2 \\
\hline $1 / 3(E M+$ water hyacinth $+O x)$ & 466.0 de & $10.5 \mathrm{e}$ & $17.0 \mathrm{def}$ & $493.5 \mathrm{def}$ & 0.49 & 80.4 & $18.0 \mathrm{~cd}$ & 83.8 & 3 & $7.8 \mathrm{bc}$ & 92.5 & 2 \\
\hline $1 / 3$ (turmeric + water hyacinth + Ox) & $427.0 \mathrm{def}$ & $17.5 \mathrm{de}$ & $17.5 \mathrm{def}$ & $462.0 \mathrm{efg}$ & 0.46 & 81.7 & $16.5 \mathrm{de}$ & 85.1 & 3 & $4.5 \mathrm{c}$ & 95.7 & 2 \\
\hline $1 / 4(\mathrm{EM}+$ turmeric + water hyacinth $+\mathrm{Ox})$ & 329.0 ef & $5.8 \mathrm{e}$ & 8.5 ef & $343.3 \mathrm{gh}$ & 0.34 & 86.4 & $10.3 \mathrm{e}$ & 90.7 & 2 & $3.8 \mathrm{c}$ & 96.3 & 2 \\
\hline Oxamyl & $288.0 \mathrm{f}$ & $3.5 \mathrm{e}$ & $5.3 \mathrm{f}$ & $296.8 \mathrm{~h}$ & 0.30 & 88.2 & $8.0 \mathrm{e}$ & 92.8 & 2 & $3.8 \mathrm{c}$ & 96.3 & 2 \\
\hline $\mathrm{N}$ alone & $2333.0 \mathrm{a}$ & $65.0 \mathrm{a}$ & $121.1 \mathrm{a}$ & $2519.0 \mathrm{a}$ & 2.52 & 0.0 & $110.8 \mathrm{a}$ & -- & 5 & $104.1 \mathrm{a}$ & -- & 5 \\
\hline $\mathrm{LSD}_{\mathrm{P}=5 \%}$ & 112.0 & 9.2 & 17.6 & 112.1 & --- & --- & 10.0 & --- & --- & 7.9 & --- & -- \\
\hline
\end{tabular}

Each value is a mean of four replicates. * Initial population $(\mathrm{Pi})=1000$ egg of $M$. incognita $* *$ Rate of build-up $(\mathrm{RF})=\frac{\text { Final population }(\text { pf })}{\text { Initial population }(\text { pi })}$ *** Root gall index (RGI) or Egg mass indes (EI): $0=$ no galling or egg masses; 1= 1-2 galls or egg masses; $2=3-10$ galls or egg masses 3=11-30 galls or egg masses; $4=31-100$ galls or egg masses; $5=$ more than 100 galls or egg masses.

Data in Table (4) illustrate the leverage of biofertilizer EM or water hyacinth or turmeric dried-leaf powders as alone or mixed applications on nitrogen, phosphorus, potassium conc., chlorophyll and phenol total contents in leaves of tomato cv. $888 \mathrm{~F} 1$ infected with $M$. incognita at greenhouse $\left(25 \pm 3^{\circ} \mathrm{C}\right)$. In general, all tested components obviously increased the percentages of the tested items i.e. nitrogen, phosphor, potassium cons and phenol contents as well as decrease total chlorophyll percentages to certain extent. It is attractive to note that all experienced treatments recorded significant increase in nitrogen, phosphor, potassium and total phenol concentration with different degrees greater than that nematode only (Table 4). Amongst the solitary treatments, bio-fertilizer EM at $5 \mathrm{ml}$ ranked first in increase percentages of nitrogen, phosphor and potassium cons and total phenol conc. by values of $20.8,11.3,10.9$ and $34.0 \%$, for $\mathrm{N}, \mathrm{P}, \mathrm{K}$ respectively, followed by water hyacinth dried leaf powder at $5 \mathrm{~g}$ in this respect. Meanwhile, the binary treatments, turmeric dried leaves powder plus oxamyl at its half dose compassed the maximum concs of $\mathrm{N}$ (37.4\%), $\mathrm{P}(24.7 \%), \mathrm{K}(25.8 \%)$ and phenols (58.7\%), respectively. Furthermore, an understandable synergetic action was occurred in rising N, P, K concs and phenols when added oxamyl to dried leaf powders of turmeric and water hyacinth at triple dose each as with values of 61.9, 38.7, 27.9 and 75.6\% , respectively. However, a higher increase percentages of N, P, K and total phenol was recorded by the tetra application $-1 / 4$ (EM + turmeric + water hyacinth + Ox)- with values of 71.6, $42.3,40.3$ and $78.5 \%$, respectively that was greater than whole treatments in this respect even that of the healthy plants.

Relating to chlorophyll total contents in tomato leaves infected by $M$. incognita under the stress of the tested treatments, the single ones showed the high reduction percentage values that ranged between 0.8 to $14.8 \%$; 9.2 to $14.2 \%$ for dual application; 17.3 to $60.0 \%$ for triple application and $83.6 \%$ for tetra application respectively.(Table, 4 ).

Undoubtedly the utilization of bio-fertilizer EM and dried leaf powder of water hyacinth or turmeric either as single or integrated applications as compared to oxamyl on $M$. incognita reproduction have an significant role in reduce nematode reproduction factor (RF) on tomato seedlings, where the dual, triple and tetra tested applications recorded greater results than single materials did. Meanwhile, when nematicide added to the triple treatment to be $[1 / 4$ (bio-fertilizer EM + water hyacinth dried-leaf powder + turmeric dried-leaf powder + oxamyl)], a high synergistic action stated in diminishing final nematode population, numbers of galls and egg mass with values of $97.4,86.5$ and $91.5 \%$, respectively, which are confirming by the observations of Youssef et al (2015) who stated that the root knot nematode criteria was reduced by aqueous extracts of ginger and curcuma on eggplant as soil drench applications at three rates of 2.5, 5 and $10 \%$. Conversely, Cheng \&Yingchun (2013) revealed that nematode parameters were higher affected at plots treated by effective microorganisms (EM) comparing other compost plots and soil nematodes are more considerable at effective micro-organisms compost plots. The nematicidal effect of the (EM) may be referred to their high lactic acid bacteria, yeast contents and photosynthetic bacteria as indicated by Kyan et al., (1999). One of numerous factors affect nematode injure is organic acids such which released during the organic materials fractionation (McBride et al., 2000), however slight information are known concerning the directly effects of low organic acids molecular-weight for nematode management (Yunhee \& Hokim, 2014). 
Furthermore, the activist increase values of nitrogen, phosphorus and potassium concentration was linked within any integrated tested applications of such materials along with insert the nematicide, a state that is supported by the data of El-Sherif \& Ismail (2009) who stated that the dual treatment of bacteria $(B t)$ with the nematicide (oxamyl) exceeded that single application of each one regarding to nitrogen, phosphor and potassium cons. in soybean plant under nematode infection. Meanwhile, the same trend was occurred in the case of total phenol content on tomato seedlings infected by $M$. incognita, which supported by the data of kesba (2010) whom revealed that using of humic and fulvic acids extensively enhanced the levels of non-enzymatic antioxidants molecules inclusive phenol contents grape infected by Rotylenchulus reniformis or T. semipenetrans, chiefly at organic acids upper conc. Phenolic compounds in plants is essential for many vital processes specially resistance to pathogens as plant defense (Kosuge, 1969). Nevertheless, negative correlation between the tested singly and concomitantly components tested treatments as regards to the decrease of chlorophyll total content, a situation which was in conformity with those reported by El-Sherif \& Ismail (2009) in respect to soybean plants under $M$. incognita infecting.

Table 4. Nitrogen, phosphorus and potassium concentrations, total chlorophyll and phenolcontents in leaves of tomato cv. 888 F1 infected with Meloidogyneincognita as influenced by bio-fertilizer EM and dried powder of water hyacinth or turmeric either alone or mixed as double or triple or tetra applications in comparison with oxamyl under greenhouse conditions $\left(25 \pm 3^{\circ} \mathrm{C}\right)$

\begin{tabular}{|c|c|c|c|c|c|c|c|c|c|c|c|c|}
\hline \multirow{3}{*}{ Treat. } & \multicolumn{12}{|c|}{ Chemical components of leaves } \\
\hline & \multirow[b]{2}{*}{$\begin{array}{l}\text { N\% } \\
\mathrm{mg} / \mathrm{g}\end{array}$} & \multirow[b]{2}{*}{$\begin{array}{c}\text { Inc. } \\
\%\end{array}$} & \multirow[b]{2}{*}{$\begin{array}{l}\text { P\% } \\
\text { ppm }\end{array}$} & \multirow[b]{2}{*}{$\begin{array}{c}\text { Inc. } \\
\%\end{array}$} & \multirow[b]{2}{*}{$\begin{array}{l}\text { K\% } \\
\text { ppm }\end{array}$} & \multirow[b]{2}{*}{$\begin{array}{c}\text { Inc. } \\
\%\end{array}$} & \multicolumn{4}{|c|}{ Chlorophyll content mg/g F.WT. } & \multirow{2}{*}{$\begin{array}{c}\text { Total } \\
\text { phenol } \\
\text { mg/g }\end{array}$} & \multirow[b]{2}{*}{$\begin{array}{c}\text { Inc. } \\
\%\end{array}$} \\
\hline & & & & & & & $\begin{array}{c}\mathrm{A} \\
\mathrm{mg} / \mathrm{g}\end{array}$ & $\begin{array}{c}\text { B } \\
\mathrm{mg} / \mathrm{g}\end{array}$ & $\begin{array}{l}\text { Total } \\
\mathrm{mg} / \mathrm{g}\end{array}$ & $\begin{array}{c}\text { Red. } \\
\%\end{array}$ & & \\
\hline Bio-fertilizer EM 5ml & 34.9 & 20.8 & 0.216 & 11.3 & 18.19 & 10.9 & $0.535 \mathrm{~h}$ & $0.434 \mathrm{~d}$ & $0.969 \mathrm{de}$ & 12.4 & $313.07 \mathrm{f}$ & 34.0 \\
\hline Turmeric dry-leaf powder $5 \mathrm{~g}$ & 32.7 & 13.1 & 0.202 & 4.1 & 17.85 & 8.8 & $0.515 \mathrm{~h}$ & $0.347 \mathrm{e}$ & $0.869 \mathrm{f}$ & 0.8 & $273.8 \mathrm{~g}$ & 17.2 \\
\hline Water hyacinth dry-leaf powder $5 \mathrm{~g}$ & 33.6 & 16.3 & 0.213 & 9.8 & 17.98 & 9.6 & 0.619 ef & $0.371 \mathrm{e}$ & $0.990 \mathrm{de}$ & 14.8 & $310.3 \mathrm{f}$ & 32.8 \\
\hline $\left.1 / 2^{(E M}+O x\right)$ & 37.2 & 28.7 & 0.225 & 16.0 & 23.01 & 10.7 & $0.643 \mathrm{e}$ & $0.336 \mathrm{e}$ & $0.979 \mathrm{de}$ & 13.6 & $363.93 \mathrm{~d}$ & 55.7 \\
\hline $1 / 2($ turmeric $+O x)$ & 39.7 & 37.4 & 0.242 & 24.7 & 20.63 & 25.8 & $0.578 \mathrm{~g}$ & $0.363 \mathrm{e}$ & $0.941 \mathrm{e}$ & 9.2 & $370.8 \mathrm{~d}$ & 58.7 \\
\hline $1 / 2^{\text {(water hyacinth }+O x)}$ & 37.9 & 31.1 & 0.242 & 24.7 & 19.79 & 20.7 & $0.598 \mathrm{fg}$ & $0.387 \mathrm{e}$ & $0.984 \mathrm{de}$ & 14.2 & $360.27 \mathrm{~d}$ & 54.2 \\
\hline $1 / 3(\mathrm{EM}+$ turmeric $+\mathrm{Ox})$ & 43.9 & 51.9 & 0.276 & 17.5 & 19.79 & 20.7 & $0.656 \mathrm{e}$ & $0.355 \mathrm{e}$ & $1.011 \mathrm{~d}$ & 17.3 & $342.9 \mathrm{e}$ & 46.7 \\
\hline $1 / 3(E M+$ water hyacinth $+O x)$ & 44.3 & 53.3 & 0.221 & 13.9 & 20.63 & 25.8 & $0.848 \mathrm{c}$ & $0.473 \mathrm{~d}$ & $1.320 \mathrm{c}$ & 53.1 & $391.47 \mathrm{c}$ & 67.5 \\
\hline $1 / 3$ (turmeric + water hyacinth $+\mathrm{Ox}$ ) & 46.8 & 61.9 & 0.269 & 38.7 & 20.98 & 27.9 & $0.946 \mathrm{~b}$ & $0.433 \mathrm{~d}$ & $1.379 \mathrm{~b}$ & 60.0 & $410.27 \mathrm{~b}$ & 75.6 \\
\hline $1 / 4(\mathrm{EM}+$ turmeric + water hyacinth + Ox $)$ & 49.6 & 71.6 & 0.228 & 42.3 & 18.15 & 40.3 & $0.951 \mathrm{~b}$ & $0.632 \mathrm{a}$ & $1.583 \mathrm{a}$ & 83.6 & $417.13 \mathrm{ab}$ & 78.5 \\
\hline Oxamyl & 41.9 & 45.0 & 0.226 & 16.5 & 18.62 & 13.5 & $0.726 \mathrm{~d}$ & $0.573 \mathrm{~b}$ & $1.298 \mathrm{c}$ & 50.6 & $421.8 \mathrm{a}$ & 80.5 \\
\hline $\mathrm{N}$ alone & 28.9 & --- & 0.194 & --- & 16.4 & --- & $0.513 \mathrm{~h}$ & $0.355 \mathrm{e}$ & $0.862 \mathrm{f}$ & --- & $233.7 \mathrm{~h}$ & --- \\
\hline Plant free of N \&any treatment & 47.3 & 63.7 & 0.251 & 29.4 & 18.46 & 12.6 & $1.044 \mathrm{a}$ & $0.530 \mathrm{c}$ & $1.574 \mathrm{a}$ & 82.6 & $267.1 \mathrm{~g}$ & 14.3 \\
\hline $\mathrm{LSD}_{\mathrm{P}=5 \%}$ & --- & --- & --- & --- & --- & --- & 0.03 & 0.033 & 0.41 & --- & 9.34 & --- \\
\hline
\end{tabular}

$\mathrm{Pi}=1000$ eggs of $M$. incognita *Each value is a mean of three replicates.

Means in each column followed by the same letter(s) did not differ at $\mathbf{p}<\mathbf{0 . 0 5}$ according to Duncan's multiple-range test.

$\mathbf{N}=$ Nitrogen, $\mathbf{P}=$ Phosphorus, $\mathbf{K}=$ Potassium, $\quad * *$ Increase $\%=\frac{\text { Treatment }-\mathrm{N} \text { alone }}{\mathrm{N} \text { alone }} \times 100$

\section{REFERENCES}

Arutselvi R., T. Balasaravanan, P. Ponmurugan, N. MuthuSaranji and P. Suresh (2012).Phytochemical screening and comparative study of anti microbial activity of leaves and rhizomes of turmeric varieties. Asian J. Plant Science and Research. 2 (2): 212-219.

Chai, T. T., J. C.Ngoi and F. C.Wong (2013). Herbicidal potential of Eichhornia crassipes leaf extract against Mimosa pigra andVignaradiata. International Journal of Agriculture and Biology. 15 (5): 835-842.

Cheng Hu \&Yingchun Qi (2013).Effective microorganisms and compost favor nematodes in wheat crops. Agron. Sustain. Dev. (2013) 33:573-579.

Christos A. Damalas, (2011). Potential uses of turmeric (Curcuma longa) products as alternative means of pest management in crop production. j. Plant omics, 4(3): 136-141.

Duncan, D.B. (1955). Multiple rang and multiple, F-test Biometrics, 11: 1-42.
El-Sherif, A. G. and F. Ismail Amona (2009). Integrated management of Meloidogyne incognita infecting soybean by certain organic amendments, Bacillus thuringiensis, Trichodermaharzianum and Oxamyl with reference to NPK and total chlorophyll status. Plant Pathology J. 8(4):159-164.

Gomez, K. A. and A. A. Gomez, (1984). Statistical Procedures for Agriculture Research. 2nd Ed., June Wiley \& Sons. Inc. New Yourk.

Helrich, K. (ED) (1990).Official methods of analysis of the association of official analytical chemists. 2 volumes . Arlington: AOAC. 15th ed. 2 volumes. $28 \mathrm{~cm}$. Book number: 7027.

Higa, T. and G. N. Wididana (1991).The Concept and Theories of Effective Microorganisms. pp.118-124. In: J.F. Parr, S.B. Hornick and C.E. Whitman (eds.) Proc. Ist Intl. Conf. on Kyusei Nature Farming U.S. Department of Agriculture, Washington., D.C., USA

Hussey, R. S. and Barker, K. R. (1973). A comparison of methods of collecting inocula of Meloidogyne spp. including a new technique. Pl. Dis. Reptr., 57: 19251928. 
Kaur, C. and H. C. Kapoor, (2002). Anti-oxidant activity and total phenolics content of some Asian vegetables. International J. Food Sci., and Technol., 37, 153-161.

Kesba, H. H. (2010). Biochemical alterations in grape infected with three phytonematode species with emphasis on root-knot nematode control. Egyptian J. Agronematol. 9(2): 116-131.

Kishore, S. (2000).Response of Effective Micro-organisms (EM) and other Nutrients to Rice and Wheat under Field conditions at Khumaltar, Nepal. EM World J., $1(1): 40-44$.

Kosuge, T. (1969). The role of phenols in host response to infection. Annual Review Phytopathol., 7: 195-222.

Kyan, T., M.Shintani, M. Sakurai, H. Ohashi, A. Fujisawa and S. Pongdit (1999).Kyusei nature farming and the technology of effective microorganism. Atami (Japan), Asian Pacific Natural Agricultural Network.

Lata, N. and D.Venapani (2010). Preliminary phytochemical screening of Eichhornia crassipes: The world's worst aquatic weed. Journal of pharmacy Research, 3(6): 1240-1242.

Machinney, G. (1941).Absorbtion of light by chlorophyll solutions. J. Biol. Chem., 140, 315-332.

McBride, R. G., R. L.Mikkelsen, and K. R.Barker, (2000). The role of low molecular weight organic acids from decomposing rye in inhibiting root-knot nematode populations in soil. Appl. Soil Ecol. 15:243-251.

Ranganna, S. (1979).Manual analysis of fruit and vegetable products.DataMagrow Hill Publishing Company Limited New Delhi 634p.
Sikora, R.A. and E. Fernandez (2005).Nematodes parasites of vegetables. In: Plant-Parasitic Nematodes in Subtropical and TropicalAgriculture, ed. Luc, M., Sikora, R.A. and Bridge, J. 2nd edition, CABI Publishing, pp319-292.

Sofowora, A. (1993). Medicinal plants and Traditional medicine in Africa, 2nd edition, spectrum books, Ibadan, Nigeria, pp289.

Taylor, A. L. and J. N. Sasser (1978).Biology, identification and control of root-knot nematode (Meloidogyne spp.). Raleigh: North Carolina state Univ. Graphics.

Trease, G.E. and W.C. Evans (1989).Pharmaognosy.13th edition, ELBS, Oxford University press, London, UK, pp245-263.

Trudgill, D.L. and V.C. Block (2001).Apomictic, polyphagous root-knot nematodes: exceptionally successful and damaging biotrophic root pathogens. Annual Review of Phytopathology. 39: 53-77.

Youssef M. M. A., Wafaa M. A. El-Nagdi and Mona G. Dawood (2015).Population density of root knot nematode, Meloidogyne incognita infecting eggplant as affected by medicinal plant aqueous extracts. App. Sci. Report. 10(1), 2015: 8-11.

YunheeSeo and Young Ho Kim (2014).Control of Meloidogyne incognita Using Mixtures of Organic Acids Plant Pathol. J. 30(4): 450-455.

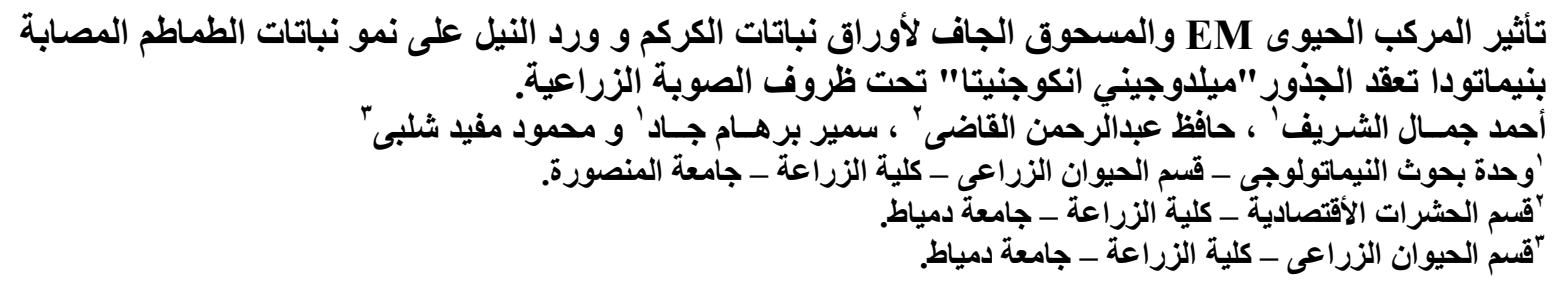

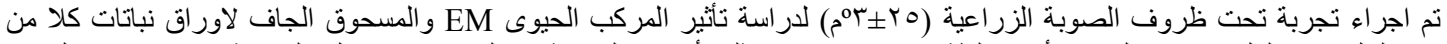

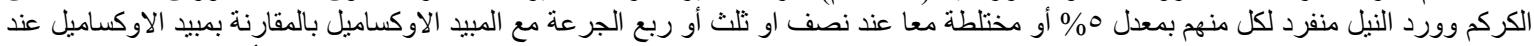

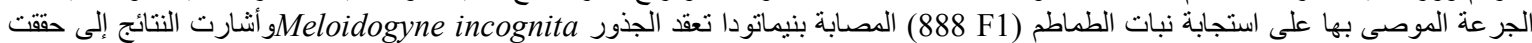

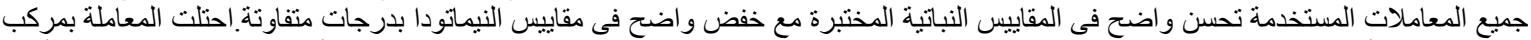

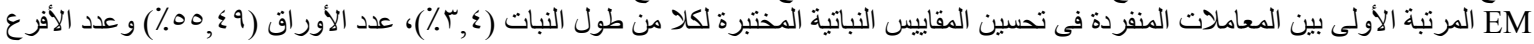

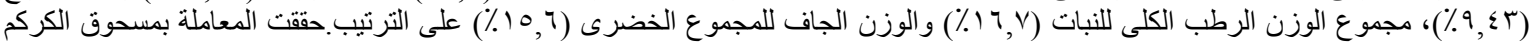

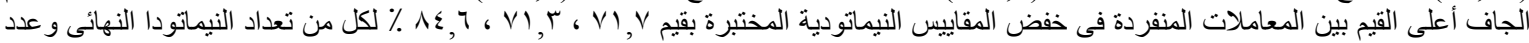

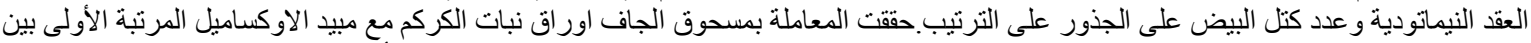

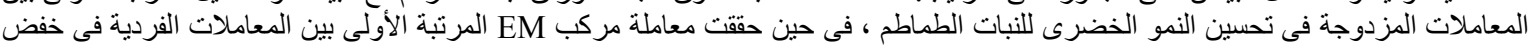

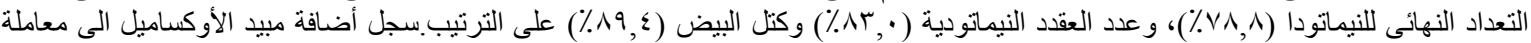

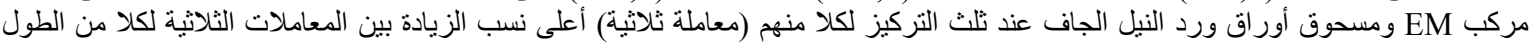

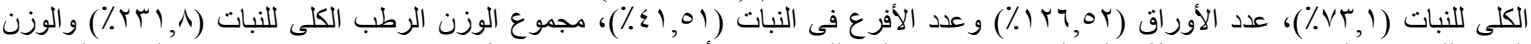

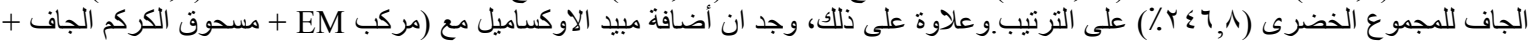

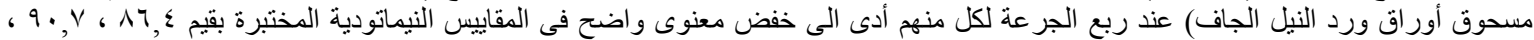

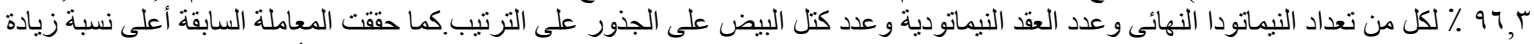

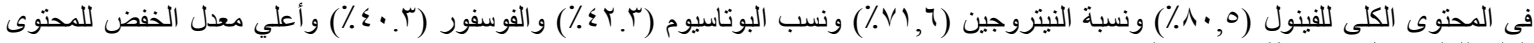

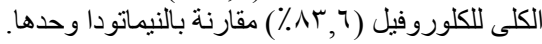

